\title{
CONDITIONAL SENTENCES IN DELIVERING A MESSAGE IN A NEWSPAPER
}

\author{
Oleh: \\ Hiace Vega Fernando Siahaan ${ }^{1)}$, \\ Andi Jaihutan Silitonga ${ }^{2)}$ \\ University of Darma Agung, Medan 1,2) \\ E-mail: \\ hiace12@yahoo.com ${ }^{1)}$ \\ andijaihutansilitonga@gmail.com ${ }^{21}$
}

\begin{abstract}
This study dealt with the using of conditional sentences in delivering a message especially in a newspaper. The purposes of this study was to describe the conditional sentences that occurred in the opinion texts and to derive the dominant category of conditional sentences in delivering a message in a newspaper then to reasoning why it was actualized in the way it was. This study conducted by using descriptive method with a qualitative approach. The data of this study were the opinion texts from the daily newspaper of The Jakarta Post. Determining, identifying, and analyzing were the steps in analyzing the data. The findings of this research show that all the types of conditional sentences are used in delivering the message in the opinion texts in The Jakarta Post. The using of conditional type I is $52,70 \%$; type II is $14,19 \%$; type III is $0,68 \%$ and 0 conditional is $32,43 \%$. So from the findings it shows that the most dominant type that used in opinion texts in The Jakarta Post is conditional sentences type I. The findings of this study are very useful for the editors of newspaper in editing the news before it is printed. They need to know conditional sentences well in order to relate one clause to another clause in delivering the message so the information can be understood by the readers easily. By knowing the conditional sentences well it will be easier to know and to understand the message written down in the newspaper.
\end{abstract}

Keywords: conditional sentences, opinion text, grammatical, newspaper.

\section{INTRODUCTION}

One of the important patterns in English language is 'conditional sentence'. It has been used to refer to a number of sentence types. Sometimes it is used as an assumption concept that encompasses all instances of delaying a sentence. Sometimes it is used interchangeably with a particular kind of sentence deferment. In this case the
Indonesian students should study the conditional sentence because this sentence is related to the implicit meaning on three types of conditional. (Armstrong et al 2013:10)

Thomson and Martinet (1995: 197) say that conditional sentence has two parts are "if"-clause and main clause. They also state that conditional sentence has three kinds or types; in which each kind contains 
a different pair of tenses in some variations. Conditional type I refer to real conditional or possible situations, type II refers to information in unreal conditional or improbable situations, type III refers to information in the past conditional because it concerns only past situations with hypothetical results.

In this case, language plays an important role in delivering a message. As we have already known that language is divided into two types, namely: written language and spoken language. This study focuses on the written language that used in a newspaper. The researcher takes newspaper rather than a textbook as the object of the study because the language that used in newspaper and textbook are very different each other. In the language of newspaper, the language that used is not too formal and the impression is to provide and updated information. Meanwhile, the language in the textbook is more likely to use formal language and its information is more emphasize on scientific information rather than the information itself.

Based on the researcher's experience during reading a newspaper, there is some information in the newspaper used conditional sentences, and this makes some of the readers do not understand the meaning. As we know that each type of conditional sentences has different meaning. In this researchers emphasize the analysis of conditional sentences in a newspaper. Since there are many kinds of newspaper, this research is going to analyze the opinion texts in The Jakarta Post Newspaper especially the use of conditional sentences in the opinion text in order to find out how the reader can know the relation of the clauses in order to get the meaning of information in text so the reader can get better understanding about the information from a newspaper.

\section{REVIEW OF LITERATURE Conditional Sentences}

Conditional sentence is something that has to be fulfilled before something else can happen. Besides that, conditional sentences are used to express the cause and effect or temporal sequences of the two events. Conditional sentence contains two clauses, they are: the condition clause and the subsequent clause that are dependent on each other.

A conditional sentence describes the condition that is necessary for a particular result to occur. The conjunctions; if, even if, when, whenever, whether, and unless often appear in conditional sentences. The meaning of conditional sentences determines which verb tenses to be used in the independent and subordinate clauses (Lane and Lange, 1993).

Thomson and Martinet (1995:197) write that conditional sentences have two parts: if clause and main clause. Meanwhile, according to Elliot (2006:4), a conditional sentence is a two clause sentence in which the first clause states a supposition or hypothesis and the second clause states the results if that condition is met.

\section{Opinion Texts}

Opinion text is basically just writing about our opinion about something or a certain subject. 
Examples: if your subject was online transportation, you could say that you have a positive opinion of them because it can make everything simple in delivering something. In general, an opinion is a judgment, viewpoint, or statement that is not conclusive. Every people have different opinion of something based on the context.

Text should be based on the context. Thus, context has a part to play; it uses different language in different situations with different people. On the other hand, it means different context will have a different text. Ellis (2003:80) defines that the context of an utterance can mean two different things that refer to the situation in which the utterance is produced; this is the "situational context". Both types of context influences the choice of language forms and therefore have an effect on output. In this sense, the context has relation to linguistics meaning. It means that the meaning must relate to context.

\section{Types of Conditional Sentences}

There are many types of conditional sentences based on the experts of linguistics. In general there are three types of conditional sentences but most grammar books tend to recognize four basic configurations of tenses in conditional sentences which vary in structure according to the time that we are talking about (past, present or future) and the meaning. These four types are normally referred to as the zero, first, second and third conditionals. In conditional sentences have two parts: the ifclause and the main clause. In the sentence "If she studies hard she will pass the test", 'if she studies hard' is if- clause and 'she will pass the test' is main clause. Here some types of conditional sentences based on some experts:

McCarthy (2008) and Yanti D, (2018) states that most students focus on four common patterns of conditional sentences or if-clauses which are often called zero, first, second and third conditionals. In English we have four ways to make conditional (if) sentences. Here is how to make them:

\section{Zero (0) Conditional}

This type is used for scientific facts or general truths. 'If' can be substituted for 'when'. For examples:
a) If you boil water to $100^{\circ} \mathrm{C}$, it boils.
b) When you boil water to $100^{\circ} \mathrm{C}$, it boils.
c) If there is a shortage of any product, prices of that product go up.
d) My parents get angry if I come home late.
e) If you want to leave a message, speak after the tone.

2. First Conditional

This type is used with 'will/can + base verb' for a probable future result. For examples:
a) If you study hard, your English will improve.
b) If I get enough sleep, I will feel better.
c) If you swallow some of the cleaning fluid, it will kill you.
d) If I get a little humility, I will be perfect.
e) I will a castle, if I am a millionaire.

3. Second Conditional 
This type uses the 'simple past' with 'modal + base verb' for imagined, impossible or unreal future situations. For examples:
a) If I won the lottery, I would buy a plane.
b) If you met Johnny Deep, what would you ask him?
c) We wouldn't finish in time unless everyone worked faster.
d) If I went to London, I could visit the British Museum.
e) You'd get fatter if you ate too much.

\section{Third Conditional}

This type uses the 'past perfect' with 'modal + have + past participle'. It is usually used to express a past regret about something which did not happen in the past. For examples:

a) If I had won the lottery, I would have bought a plane.

b) If I had been taller, I could have played in the NBA.

c) If you had visited Scotland, you could have visited Edinburgh Castle.

d) If we'd taken the first turning, we would have been at home by now.

e) The meeting would've finished before 1:00 if you'd said less.

\section{RESEARCH METHODOLOGY}

This study was a qualitative research, it was because of the kind of data were qualitative data. Dey (2005:14-15) states that qualitative data are often presented as richer and more valid. On the other hand, it is often dismissed as too subjective because assessments are not made in term of established standard. Meanwhile, qualitative method means that all data are analyzed in the form of sentences and words, not in the form of number (Wilkinson, 2004:7)

In addition, this research also uses descriptive explanative, means that it explains why conditional sentences are applied in Opinion Texts and it needs some reasons. Descriptive is the collection of data to give explanation or description about the even or accuracy of the report (Moleong, 2002:6). By using this method the data were analyzed, and the result of the research is the description of conditional sentences in a newspaper.

In analyzing data this study based on Miles and Huberman (2014) that said there is some important process, they are: 1) data collection, 2) data condensation, 3) data display, 4) conclusion: drawing and verifying. The process of analysis data which figured by Miles and Huberman (2104) is formed cycle. The cycle can be seen in the following figure:

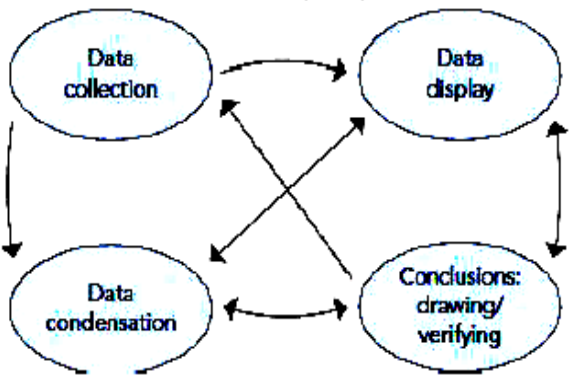

Figure 4.1

Component of Interactive Data

Analysis (Miles and Huberman, 2014)

\section{FINDINGS AND DISCUSSIONS}

Having collecting the data taken from the The Jakarta Post 
especially the opinion texts, it was found that there were 87 opinion texts that consist of 148 sentences that used conditional sentences in delivering a message. After having the data, then the data were determining identifying and analyzing based on the types of conditional sentences and there were some findings.

Firstly, based on the analysis that has been done it was found that all of the types of conditional sentences were used in opinion texts, they were: conditional type I, conditional type II, conditional type III and 0 conditional. Secondly, after doing the analysis of conditional sentences in opinion texts, it was found that from all the types of conditional sentences that were found in opinion texts shows that the percentage of the using of conditional sentences were different each other, they were: conditional type I was $52,70 \%$, conditional type II $14,19 \%$, conditional type III was $0,68 \%$ and 0 conditional was 32 , $43 \%$. Thirdly, from the four types of conditional sentences it was found that the most dominant type of conditional sentences that used in opinion texts was conditional type I. conditional type I was dominantly used because conditional type $\mathrm{I}$ is a factual or real condition.

In delivering the message in a newspaper it is better to use conditional type I to give clear information and also factual information to the reader so the reader can grasp the meaning of the information easily that given to them by reading a newspaper of The Jakarta Post. The percentage of types of conditional sentences in opinion texts of The Jakarta Post can be seen as the following table:

\section{Table 1: The Percentage of Types of Conditional Sentences in Opinion Texts}

\begin{tabular}{|c|l|c|}
\hline No & $\begin{array}{c}\text { Types of Theme of } \\
\text { Textual Function }\end{array}$ & $\begin{array}{c}\text { Percentage } \\
(\mathbf{\%})\end{array}$ \\
\hline 1. & Type I & $52,70 \%$ \\
\hline 2. & Type II & $14,19 \%$ \\
\hline 3. & Type III & $0,68 \%$ \\
\hline 4. & Type Zero (0) & $32,43 \%$ \\
\hline \multicolumn{2}{|c|}{ Total } & $\mathbf{1 0 0 \%}$ \\
\hline
\end{tabular}

From the table above, it concluded that the most type of conditional sentences that is used in delivering a message in a newspaper especially in opinion texts is conditional sentences type I $(52,70 \%)$. Here are some of the analysis of the types of conditional sentences that used in opinion texts of The Jakarta Post.

\section{Conditional Sentences Type I}

After doing the analysis from the 148 sentences as the data of this study it was found that there were 78 sentences that used conditional sentences type I in delivering a message in opinion texts in The Jakarta Post. The use of conditional sentences type I in opinion texts is presented as following:

1. The National Police will not charge me with defamation if I share the public perception that criminals widely believe they can make deals with the two institutions.

2. But you can get a minimum jail term if not full freedom.

3. If it meets the approval of the generals, will proceed to a referendum followed by elections next year. 
4. If however, host countries enthusiastically integrate migrants, everyone will benefit including home countries (for example, through remittances).

5. If you react calmly, they will help you grow as a person.

6. If Greece ultimately leaves the euro area, the entire currency union could unravel.

7. If panti jompo is not suitable for elderly people, how should our senior citizens be looked after in the community according to Indonesian culture?

8. The stigma of panti jompo can be minimized if the government increases the quality standards of care these facilities provide.

9. China will never succeed if it does not bring its financial reforms into closer sync with its rebalancing strategy for the real economy.

10. It will be a prestigious thing for Indonesia if Rio is the first citizen to race in $\mathrm{F}$.

\section{Conditional Sentences Type II}

After doing the analysis from the 148 sentences as the data of this study it was found that there were 21 sentences that used conditional sentences type II in delivering a message in opinion texts in The Jakarta Post. The use of conditional sentences type I in opinion texts is presented as following:

1. They would agree if Abdurrahman Wahid (their former head and Indonesia's fourth president) was named a hero.

2. This discussion would effectively vanish in six years if foreign reserves were to continue falling at the same $\$ 500$ billion annual rate recorded in 2015.

3. You would be mistaken if you imagined that bureaucrats in Chile and Colombia had more important things to do than restricting immigration

4. If capital flight were to intensify, China would ultimately be powerless to stop it.

5. They would most certainly rethink this position if capital flight were to become a more serious threat.

6. Their proxies could well become more explosive if western countries added pressure on both of them to become more democratic.

7. If it were a matter of belief, no devout believer would blow themselves up in a crowd of innocent bystanders.

8. If passed, the bill would ensure that domestic workers receive fair and transparent contracts.

9. If she were alive today, she would have likely been among the women of Rembang who are at the forefront of a demonstration which has lasted for two years.

10. It would be hilariously funny if it weren't so scary.

\section{Conditional Type III}

After doing the analysis from the 148 sentences as the data of this study it was found that only 1 sentence that used conditional sentences type III in delivering a message in opinion texts in The Jakarta Post as following:

1. If Iran had achieved a nuclear weapon, it would have 
drastically increased its power over its neighbors.

\section{Conditional Type Zero (0)}

After doing the analysis from the 148 sentences as the data of this study it was found that there were 48 sentences that used conditional sentences type Zero (0) in delivering a message in opinion texts in The Jakarta Post. The use of conditional sentences types Zero (0) in opinion texts is presented as following:

1. I wonder if I can persuade it to swap jobs with the guy who drove the bus I took home one night last week.

2. I am skeptical if this can work.

3. If it wants to maintain its monetary independence, say by the targeting inflation.

4. If it is a lot more is needed, as more children are displaced every day.

5. It allows central government to take away management of local affairs if regions do not perform.

6. This provision is only applicable if the region has not responded to guidance.

7. If the implementation goes as planned, the projects are expected to decrease distribution and logistical costs.

8. If not, we are playing a guessing game as to what is next as we stare at the partial.

9. If we piece the together and embrace the full landscape as one large vision, we do not need to stop at the borders and edges of our familiar fields.

10. If the creation of a completely new industry is too far of a leap, let us understand disruption as displacement.

\section{CONCLUSIONS}

After doing the analysis of the using of conditional sentences in delivering a message in opinion text in The Jakarta Post, it is showed that all the types of conditional sentences are used but in different occurrences. From the research findings, it concluded that the most dominant type of conditional sentences that is used in opinion text of The Jakarta Post is conditional sentences type I. It concluded that the writer of opinion texts in delivering the message want to emphasize the real or factual condition. As it is known that factual conditional tells what usually or always happens under certain conditions (situations). Besides that, it is suggested that the journalist use conditional sentences in delivering a message in making a variation of message, the readers also suggested learning more about conditional sentences in order to understand the information that written in a newspaper.

\section{REFERENCES}

Armstrong, S, Mclvor G, McNeill, F. and McGuinness P. 2013. International Evidence Review of Conditional (Suspended) Sentences. Canbera. Canbera University press

Azzar, Betty Schrampfer. 1999. Understanding and Using English Grammar. New York: Prentice Hall Regents.

Brown, H.D. 1982. Teaching by Principles: An Interactive Approach to Language 
Pedagogy. New Jersey: Prentice Hall Regents.

Best, J.W. 1981. Research in Education. Englewood Cliffs. New Jersey: Pentice Hall.

Biklen, S., \& Bogdan, R.C. 1992. Qualitative Research for Education: An Introduction to Theory and Methods. New York: Allyn and Bacon.

Eastwood, Jhon. 1994. Oxford Guide to English Grammar. Oxford. Oxford University Press.

Elliot, William E. 2006. Conditional Sentences In The New Testament. Digitized by Ted Hilderandt, Massachussets: Gordon College.

Ellis, M. 2003. An Introduction to General Linguistics. Oxford: Oxford University.

Emery, M; Edwin, E \& Nancy L.R. 2000. The Press and America. Boston: Allyn and Bacon.

Dey, Ian. 2005. Qualitative Data Analysis A User-Friendly Guide for Social Scientists. London: Routledge.

Folkerts, J and Dwight, L. 2002. Voices of a Nation. Boston: Allyn and Bacon. Hornby. A.S. 1995. Oxford Advanced Learners Dictionary of Current English. Oxford: Oxford University Press.

Mahnke,M. Kathleen. 2005. Grammar Links 2-A Theme-
Based Course for Reference and Practice. Boston: Houghton Mifflin Company.

Miles, and Huberman. 1984. Qualitative Data Analysis: A Sourcebook of New Methods. California: Sage Publication, Inc.

Miles, and Huberman. 2014. Qualitative Data Analysis, 3rd edition. California. Sage Publication, Inc.

Moleong, L.J. 2002. Metodologi Penelitian Kualitatif. Bandung: Remaja Rosda Karya.

Nawawi, H. 2006. Metode Penelitian Bidang Sosial. Yogyakarta: Gajah mada University Press.

Nazir, M. 1998. Metode Penelitian. Jakarta: Ghalia.

Thomson and Martinet. 1995. A Practical English Grammar. New York: Oxford University Press.

Thompson, G. 1996. Introducing Functional Grammar. London: Arnold.

Wilkinson, S., Joffe, H. and Yardley, L. 2004. Qualitative Data Collection: Interviews and Focus Groups. In D. F. Marks and L. Yardley (Eds) Research Methods for Clinical and Health Psychology. London: Routledge.

Internet Sources: 
Admin. 2012. Conditional Sentences: Grammar and Usage ofIf-Clause, http://www. conditionalsentences.org/

Beare, Kenneth. 2012. Conditional Forms, About. com.Guide.http://esl.about.com /od/grammal/a/conditional.htm

Lane, J and Lange, E. 1993. Writing Clearly: An Editing Guide, Boston: Heinle and Heinle, http://www.sdc.uwo. $\mathrm{ca} /$ writing/handouts/Conditiona $1 \%$ 20Sentence.pdf.

McCarthy, Chris. 2008. How to Use "If" in Conditional Sentences, http://www. ecenglish.com/ learnenglish/

Yanti, D. (2018). Pemanfaatan Web Blog sebagai Media Distribusi Informasi Pariwisata. Jurnal Darma Agung, 26(1), 600 - 605. Retrieved from

https://jurnal.darmaagung.ac.id/inde x.php/jurnaluda/article/view/69 